\title{
The productivity of intensive pea varieties depending on the seeds treatment and foliar fertilizing under conditions of right-bank forest-steppe Ukraine
}

\author{
Mazur $\mathrm{V}^{1}$, Didur $\mathrm{I}^{1}$, Myalkovsky $\mathrm{R}^{2}$, Pantsyreva $\mathrm{H}^{1 *}$, Telekalo $\mathrm{N}^{1}$, Tkach $\mathrm{O}^{2}$ \\ ${ }^{1}$ Vinnytsia National Agrarian University, 3, Soniachna Str., Vinnytsia, Ukraine, 21008 \\ ${ }^{2}$ State Agrarian and Engineering University in Podilia, Kamyanets-Podilsky, Ukraine
}

E-mail: apantsyreva@ukr

ORCID ID: https://orcid.org/0000-0002-0539-5211, Publons: L-5102-2018.

Received 26.01.2020 Accepted 21.02.2020

\begin{abstract}
It is developed the growing technology model, which provides for the growing pea varieties under compatible presowing seeds treatment by bacterial preparations Ryzohumin and Polimiksobakteryn, and triplex using of foliar fertilizing by complex fertilizers KODA 7-21-7 in the phases of budding and green beans and KODA Complex in the phase of pouring seeds in the background of fertilization N45P60K60, which provided grain yield formation on the level of $4.01 \mathrm{t} / \mathrm{ha}$ in class Tsarevych and $4.31 \mathrm{t} / \mathrm{ha}$ in class Ulus, where collection of crude protein was $1.02 \mathrm{t} / \mathrm{ha}$ and $1.07 \mathrm{t} / \mathrm{ha}$. It is established the dependence between the pea yield size and weather conditions during the growing period. It is created the optimal conditions of mineral nutrition for pea plants due to using of bacterial fertilizers and foliar fertilizers, which promoted not only great yield formation, but also significantly increasing of biochemical indexes and, as a result - the increasing of crude protein content till $24.81-25.44 \%$ and its collection - till $1.02-1.07$ t/ ha.
\end{abstract}

Keywords: Pea; Presowing seeds treatment; Foliar fertilizing; Yield; Seed quality

\section{Introduction}

The main task of modern agriculture in Ukraine is increasing of grain cultures productivity, which will be promote the formation of plants recourses stock, the providing of livestock by high-quality fully feed, and population - by food products.

The pea is taking the important place in solving of this task. Its grain have got approximately $50 \%$ of carbohydrates and $26 \%$ saturated of essential amino acids, minerals and vitamins protein, that's why it is widely using in mixed fodder production for manufacturing of balanced concentrated feed. The short growing period and ability to fixation of atmospheric nitrogen makes pea like the best predecessor for winter wheat. Besides, that the plants ensure themselves on $2 / 3$ by nitrogen, they leave $60-100 \mathrm{~kg}$ of easily accessible nitrogen for subsequent culture. By using compatible bacterization by biofertilizing preparations on the basic of specific kinds of rhizobia and phosphate mobilization bacteria is ability to increase the efficiency of symbiotic nitrogen fixation on 13$30 \%$ and formation high-yield pea plantings. The wheat field doesn't get approximately 1 million ha of the greatest predecessor pea in Ukraine's crop rotations, that's why the implementation of new high-productive pea varieties of intensive type, which are suitable for direct harvesting will provide the expansion of its acreages. Hence is arise the necessity of conducting the deep investigations with these varieties, to estimate their reaction on using of bacterial preparations on the base of nitrogen-fixing strains and phosphate mobilization bacteria, and complex fertilizers with content of macro- and microelements for foliar fertilizing. Besides, it is extremely important to determine how these methods of cultivation technology of pea under conditions of right-bank ForestSteppe will influence on the processes of symbiotic and photosynthetic activity and realization of moustaches peas varieties genetically potential and grain productivity in general. Marked questions are quite relevant and require proper scientific justification for the conditions of the region.

\section{Analysis of Recent Research and Publications}

The using of biological bacteria compositions in combination with microelements while seeds processing stimulates the metabolic processes, is directing change the speed of initial growth reactions, provides intensive development of root system. The newest investigations shown, that beside the plants roots nutrition there is air nutrition. That's why the plant foliar fertilizing by microelements became a widespread agricultural method. It allows to optimize the plant macro- and microelements nutrition in some vegetations periods and in the final result - to increase the yield, and improve the quality of crop production. In the studies is established that pea growing with fertilizing of nitrogen by scheme $N_{30}$ till sowing $+N_{30}$ in the budding phase $+P_{60} K_{60}$ till sowing on the background of the integrated plant protection system and presowing seeds treatment by growth stimulator Emistim $\mathrm{C}$ and active strain of rhizobia Rhizobium leguminosarum, is forming the highest yield indexes $-3.48-3.98 \mathrm{t} /$ ha, raw crude protein content $22,35-23,02 \%$. 
The aim of investigations consisted of productivity formation of intensive pea varieties type depending on the influence of presowing seeds treatment and foliar fertilizing under conditions of right-bank Forest-Steppe.

\section{Materials and Methods}

The investigations were conducted during 2014-2016 years in field crop rotation of feed crops selection department in the Podillya NAAS Institute of feed and agriculture on the gray forest medium loam soils with humus content (by Tyurin) in the arable layer 2 , $10 \%$. The reaction of soil solution pHsalty $-5,1$, hydrolytic acidity of $3.5 \mathrm{mg}$ eq. $/ 100 \mathrm{~g}$ soil, the sum of absorbed bases $18.5 \mathrm{mg}$ eq./100 g soil. The content of easily hydrolyzed nitrogen (by Kornfil'd) $-6,3 \mathrm{mg}$ eq./100 g soil, mobile forms of phosphorus and exchangeable potassium (by Chirikov) - 10.8 and $7.2 \mathrm{mg}$ eq./100 g soil respectively. The most favorable conditions for growth, development and yield formation of pea were in 2014 and 2016 years, when were observed sufficiency for plants as in thermal resources, so the moisture throughout the growing season. The most hot and dry was in 2014, when the average temperature during April-July exceeded the average performance at $3,3^{\circ} \mathrm{C}$, while precipitation was only $217.2 \mathrm{~mm}, 73.8 \mathrm{~mm}$ less than the average long-term norm. The research envisaged the study of the action and interaction of three factors: A - variety; B - foliar fertilizing; $C$ - presowing seeds treatment. The ratio of these factors is $2 \times 4 \times 4$. The repeated in experiment is a quadruple, the placement of options is systematic in two storey. The square of sown area is $40 \mathrm{~m}^{2}$, of accounting area - $25 \mathrm{~m}^{2}$.

We were studied two pea varieties of without leaves type - Tsarevych and Ulus. The sowing was conducted by ordinary row kind with using seed drill $\mathrm{CH}-16$ in the first decade of April with sowing seeds norm $-1.3 \mathrm{mln}$. pcs. /ha of approved seeds.

The presowing seeds treatment were conducted by chemical preparation Vitavaks $200 \mathrm{FF}$ ( $2.5 \mathrm{l} /$ ton of seeds) just two weeks before sowing, the treatment by biological preparations was done in the same with sowing day. It was used Ryzohumin (Rhizobium leguminosarum 31), $300 \mathrm{~g}$ on hectare seeds norm and Polimiksobakteryn (Paenibacillus polymyxa KB), $150 \mathrm{~g}$ on hectare seeds norm for seeds bacterization. The foliar fertilizers were carried out by soluble complex fertilizers KODA Foul 7-21-7 (2 l/ha), which contains macro- and micronutrients ( $\mathrm{N}-7,3 \%, \mathrm{P}_{2} \mathrm{O}_{5}-21,9 \%, \mathrm{~K}_{2} \mathrm{O}-7,3 \%, \mathrm{Mn}-0,6 \mathrm{~g} / \mathrm{l}, \mathrm{Zn}-0,6 \mathrm{~g} / \mathrm{l}, \mathrm{Cu}-0,6 \mathrm{~g} / \mathrm{l}, \mathrm{Fe}-1,3 \mathrm{~g} / \mathrm{l}, \mathrm{Mo}$ $-0,01 \mathrm{~g} / \mathrm{l}, \mathrm{V}-1,2 \mathrm{~g} / \mathrm{l})$ at a dose of $2 \mathrm{l} / \mathrm{ha}$ and KODA Complex at a dose $1 \mathrm{l} / \mathrm{ha}$, which contains - amino acids - 15,0\% (Zn - 18,6 $\mathrm{g} / \mathrm{l}, \mathrm{Mn}-6,2 \mathrm{~g} / \mathrm{l}, \mathrm{Fe}-24,8 \mathrm{~g} / \mathrm{l})$.

The determination of biochemical seeds quality indexes of pea were carried out according to the methodologies "The estimation quality and animal husbandry analysis of forage " and "The biochemical methods for plants analysis. The yield quantity had been determine by gathering grain from each plot with grain combine harvester «Sampo - 130» and by weighting of each variety.

\section{Results and Discussion}

It should be noted, that on the control variants by the years of investigation (2014-2016 years) the yield of pea grain of variety Tsarevych was changing from $2.92 \mathrm{t} / \mathrm{ha}$ till $3.04 \mathrm{t} / \mathrm{ha}$, in the variety of Ulus it was from $2.97 \mathrm{t} / \mathrm{ha}$ till $3.15 \mathrm{t} / \mathrm{ha}$ (Table 1 ).

The improvements of nitrogen and phosphorus nutrition of pea plants was occurred of simultaneous presowing seeds treatment by Polimiksobakteryn and Ryzohumin, increased pea grain yield of Ulus on the background of fertilizing N45P60K60 till 3,27 t/ha or on $0,30 \mathrm{t} / \mathrm{ha}$, or $10 \%$, compared with control. The application of this method in combination with foliar fertilizing by complex fertilizers KODA increased the grain yield on $0,34-0,46 \mathrm{t} / \mathrm{ha}$ or $10,4-13,0 \%$.

A similar pattern marked increase grain productivity in a variety of Ulus, while it exceeds the sort Tsarevych to yield to $0,18-0,30$ $\mathrm{t} / \mathrm{ha}$. The using of foliar fertilizing in the budding phase by KODA Foul 7-21-7 contributed to an increase in yield of the variety Tsarevych till 3,26-3,60 t/ha, of the variety Ulus - 3,44-3,84 t/ha or on $9,2-10,1 \%$ in comparison with variants without foliar fertilizing. The duplex application of foliar fertilizing by this manure in the phases budding and green beans was increased the grain yield of peas on $0,47-0,61 \mathrm{t} / \mathrm{ha}$ or $15,8-17,4 \%$ in comparison with variants without foliar fertilizing. The triplex application of foliar fertilizing by KODA Complex in the phase of ripening seeds was increased the grain yield of variety Tsarevych on $0,58-0,74 \mathrm{t} / \mathrm{ha}$, of the variety Ulus on $0,59-0,81 \mathrm{t} /$ ha in comparison with variants without foliar fertilizing. However, the maximum grain yield of peas 4,01 t/ha in the Tsarevych variety and in the Ulus variety - 4,31 t/ha was obtained by growing with using presowing seeds treatment by composition Ryzohumin +Polimiksobakteryn on the background of mineral fertilizing N45P60K60 and carrying out the triplex foliar fertilizing of crops in the blossom phase and phase of green beans by KODA Foul 7-21-7 and in the phase of ripening seeds of pea by KODA Complex. The proportion of factors impact in peas grain yield formation is shown on Figure 1 , which is authentically in the five percent significance level. The carrying out of foliar fertilizing was provided the formation of $55 \%$ of peas grain yield, $20 \%$-presowing seeds treatment, $17 \%$ were depended on the potential of the variety and $8 \%-$ from unregulated factors.

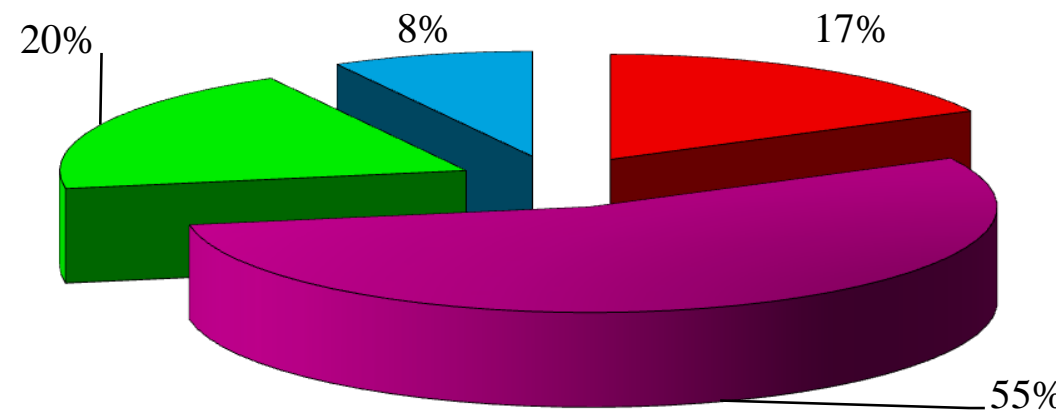

$\square$ Variety $\quad \square$ Foliar fertilizing

$\square$ Presowing seeds treatment $\square$ Other factors

Figure 1. The proportion of factors in formation of peas grain yield, \% (in average for 2014-2016). 
Table 1. Grain yield of peas depending on the impact of presowing seeds treatment and foliar fertilizing, t/ha, 2014-2016.

\begin{tabular}{|c|c|c|c|c|c|}
\hline Foliar fertilizings & $\begin{array}{l}\text { Pre sowing seeds } \\
\text { treatment }\end{array}$ & 2014 & $\begin{array}{l}\text { Years } \\
2015\end{array}$ & 2016 & Average \\
\hline \multirow{5}{*}{$\begin{array}{l}\text { N45P60K60 } \\
\text { (background) }\end{array}$} & Without treatment & 3,04 & 2,92 & 2,95 & 2,97 \\
\hline & Polimiksobakteryn & 3,16 & 3,04 & 3,04 & 3,08 \\
\hline & Ryzohumin & 3,23 & 3,09 & 3,13 & 3,15 \\
\hline & $\begin{array}{l}\text { Ryzohumin + } \\
\text { Polimiksobakteryn }\end{array}$ & 3,38 & 3,21 & 3,21 & 3,27 \\
\hline & Without treatment & 3,37 & 3,23 & 3,18 & 3,26 \\
\hline \multirow{5}{*}{ Background $+\mathrm{I}^{*}$} & Polimiksobakteryn & 3,46 & 3,35 & 3,30 & 3,37 \\
\hline & Ryzohumin & 3,54 & 3,41 & 3,43 & 3,46 \\
\hline & $\begin{array}{l}\text { Ryzohumin + } \\
\text { Polimiksobakteryn }\end{array}$ & 3,74 & 3,54 & 3,51 & 3,60 \\
\hline & Without treatment & 3,53 & 3,45 & 3,35 & 3,44 \\
\hline & Polimiksobakteryn & 3,69 & 3,53 & 3,51 & 3,58 \\
\hline \multirow[t]{3}{*}{ Background +I+II* } & Ryzohumin & 3,78 & 3,62 & 3,57 & 3,66 \\
\hline & $\begin{array}{l}\text { Ryzohumin + } \\
\text { Polimiksobakteryn }\end{array}$ & 4,00 & 3,79 & 3,72 & 3,84 \\
\hline & Without treatment & 3,65 & 3,53 & 3,46 & 3,55 \\
\hline \multirow{3}{*}{$\begin{array}{l}\text { Background } \\
+\mathrm{I}+\mathrm{II}+\mathrm{III}^{*}\end{array}$} & Polimiksobakteryn & 3,82 & 3,67 & 3,58 & 3,69 \\
\hline & Ryzohumin & 3,95 & 3,74 & 3,70 & 3,80 \\
\hline & $\begin{array}{l}\text { Ryzohumin + } \\
\text { Polimiksobakteryn }\end{array}$ & 4,19 & 3,95 & 3,88 & 4,01 \\
\hline \multicolumn{6}{|l|}{ variety Ulus } \\
\hline \multirow{6}{*}{$\begin{array}{l}\text { N45P60K60 } \\
\text { (background) }\end{array}$} & Without treatment & 3,47 & 2,80 & 3,19 & 3,15 \\
\hline & Polimiksobakteryn & 3,58 & 2,96 & 3,28 & 3,27 \\
\hline & Ryzohumin & 3,69 & 3,02 & 3,36 & 3,36 \\
\hline & $\begin{array}{l}\text { Ryzohumin + } \\
\text { Polimiksobakteryn }\end{array}$ & 3,86 & 3,17 & 3,47 & 3,50 \\
\hline & Without treatment & 3,78 & 3,11 & 3,42 & 3,44 \\
\hline & Polimiksobakteryn & 3,95 & 3,24 & 3,54 & 3,58 \\
\hline \multirow[t]{4}{*}{ Background $+\mathrm{I}^{*}$} & Ryzohumin & 4,07 & 3,32 & 3,63 & 3,67 \\
\hline & $\begin{array}{l}\text { Ryzohumin + } \\
\text { Polimiksobakteryn }\end{array}$ & 4,24 & 3,53 & 3,76 & 3,84 \\
\hline & Without treatment & 3,99 & 3,32 & 3,58 & 3,63 \\
\hline & Polimiksobakteryn & 4,18 & 3,46 & 3,71 & 3,78 \\
\hline \multirow[t]{3}{*}{ Background +I+II* } & Ryzohumin & 4,33 & 3,57 & 3,82 & 3,91 \\
\hline & $\begin{array}{l}\text { Ryzohumin + } \\
\text { Polimiksobakteryn }\end{array}$ & 4,54 & 3,80 & 4,00 & 4,11 \\
\hline & Without treatment & 4,13 & 3,42 & 3,67 & 3,74 \\
\hline \multirow{3}{*}{$\begin{array}{l}\text { Background } \\
+\mathrm{I}+\mathrm{II}+\mathrm{III} *\end{array}$} & Polimiksobakteryn & 4,31 & 3,58 & 3,81 & 3,90 \\
\hline & Ryzohumin & 4,50 & 3,72 & 3,94 & 4,05 \\
\hline & $\begin{array}{l}\text { Ryzohumin + } \\
\text { Polimiksobakteryn }\end{array}$ & 4,74 & 3,99 & 4,20 & 4,31 \\
\hline
\end{tabular}

Note:* I - Foliar fertilizing in the budding phase - KODA Foul 7-21-7; II - Foliar fertilizing in the green beans phase - KODA Foul 721-7; III - Foliar fertilizing in the phase of ripening seeds - KODA Complex.

The least significant difference $005 \mathrm{t} / \mathrm{ha}$; $\mathrm{A}$-Variety; $\mathrm{B}$ - Foliar fertilizing; $\mathrm{C}$ - Presowing seeds treatment

2014 year. A - 0,021; B - 0,029; C - 0,007; AB - 0,042; AC-0,042; BC - 0,059; $A B C-0,083$

2015 year. $A-0,024 ; B-0,034 ; C-0,009 ; A B-0,048 ; A C-0,048 ; B C-0,068 ; A B C-0,096$

2016 year. $A-0,023 ; B-0,032 ; C-0,008 ; A B-0,045 ; A C-0,045 ; B C-0,064 ; A B C-0,091$

The results of multiple regression analysis is identified the significant dependence between yield pea and hydrothermal conditions (Table 2).

Table 2. Regression models of dependence between the yield pea and the hydrothermal conditions (average for 2014-2016).

\begin{tabular}{llllll}
\hline & The regression equation & RMH & $\mathbf{R}^{2}$ & F & FT \\
Yield $(\mathrm{y} *)$, & $\mathrm{y}_{1}=-3,327+0,004 \mathrm{X}_{1}+0,004 \mathrm{X}_{2}$ & 0,987 & 0,978 & 285,20 & \\
t/ha & $\mathrm{y}_{2}=-2,454+0,015 \mathrm{X}_{1}+0,006 \mathrm{X}_{2}$ & 0,989 & 0,978 & 285,64 & $6,70 * *$ \\
& $\mathrm{y}_{1}=-3,590+0,858 \mathrm{X}_{3}-6,892 \mathrm{X}_{4}$ & 0,896 & 0,804 & 26,60 & \\
\hline
\end{tabular}

Note:* $Y_{1}-$ Tsarevych, $Y_{2}-$ Ulus; $X_{1}$ - Precipitation, $m m ; X_{3}-$ The sum of active temperatures $\left({ }^{\circ} \mathrm{C}\right) ; X_{3}-$ The average air temperature, ${ }^{\circ} \mathrm{C} ; \mathrm{X}_{4}-\mathrm{HTC}$; RMH - Multiple correlation coefficient, $\mathrm{R}^{2}$ - Coefficient of determination, $\mathrm{F}$ - Fisher criteria; FT - TableValued Fisher criteria. $* *$ - Authentically at $1 \%$ significance level. 
By the results of correlation analysis of average for the years 2014-2016 research, it is determine the dependence of peas yield from the average air temperature ( $r=0,867$ for Tsarevych and $r=0,839$ for Ulus), precipitation $(r=0,958 ; r=0,948)$, the sum of active temperatures $(r=0,989 ; r=0,987)$, HTC $(r=0,867 ; r=0,950)$, which is authentically at $1 \%$ significance level. There is debating question: is there the inverse relationship between harvest and protein content in grain? With the improvement of mineral nutrition and optimal provision of heat and moisture the protein content in the grain is increasing at once with the increase of harvest. This pattern confirms our studies where indicators of chemical composition increase with increasing of productivity.

The value of grain pea is that it contains a significant amount of crude protein. It is determined, that at using presowing seeds treatment and foliar fertilizing by complex fertilizers, and its content was increasing significantly in connection with optimization of mineral nutrition of plants during growing season. So, on the control variant on the background of mineral nutrition N45P60K60 without seeds treatment, the crude protein content of Tsarevych variety in average for 2014-2016 was 21,94\%. On the plots with background fertilizing $\mathrm{N}_{45} \mathrm{P}_{60} \mathrm{~K}_{60}$ and with presowing seeds treatment, this index was increased till $22,50-22,88 \%$. The increasing of crude protein on $1,6-2,1 \%$ occurred by the effect of foliar fertilizing, but the greatest amount of crude protein (24,81\%) was accumulated on the variant, where was used the full rate of mineral nutrition N45P60K60, presowing seeds treatment by Ryzohumin and Polimiksobakteryn and three foliar fertilizations by KODA (Table 3).

Table 3. Quality indexes of pea seeds of the variety Ulus depending on the impact of pre-seed treatment and foliar fertilizing, \% (average for 2014-2016).



Note:* I - I - Foliar fertilizing in the budding phase - KODA Foul 7-21-7; II - Foliar fertilizing in the green beans phase - KODA Foul 7-21-7; III - Foliar fertilizing in the phase of ripening seeds - KODA Complex.

It is observed the trend, under analysis of collecting peas crude protein, which is same for yield, as this index combines two values grain yield and content of crude protein. The studied factors were significantly influenced on collection of crude protein. So, presowing seeds treatment increased collection of crude protein on $0,05-0,11 \mathrm{t} / \mathrm{ha}$, foliar fertilizing by KODA on $0,20-0,27 \mathrm{t} / \mathrm{ha}$ during growing season, which is authentic at the five percent significance level. The biggest collection of crude protein in Tsarevych $-1,02 \mathrm{t} / \mathrm{ha}$, in Ulus $1,07 \mathrm{t} / \mathrm{ha}$ was obtained on the variant with mineral nutrition $\mathrm{N}_{45} \mathrm{P}_{60} \mathrm{~K}_{60}$, the using of the presowing seeds treatment by Ryzohumin and Polimiksobakteryn and three foliar fertilizations by KODA in average of three years (2014-2016), which is bigger than control variant on 0,33 t/ha and 0,38 t/ha, accordingly.

The using of presowing seeds treatment and foliar fertilizations resulted in the optimization of mineral nutrition and the appropriate changes in indicators content of phosphorus and potassium in pea grain, which were studied, ensuring their increase when imposition of studied factors. So, the phosphorus content in sort Tsarevych was $0,96-1,11 \%$, in sort Ulus $1,06-1,21 \%$, potassium content $-1,15-1,31 \%$ та 1,23-1,39\% accordingly, although the change of these macronutrients content was in the within the error limits, but sustained growth in dependence to the intensification of the process. Carbohydrates are related to the initial products of photosynthesis, organic acids are synthesized in the oxidation process from them, lipids - in the recovery process. The derivatives of hydrocarbons, as fat and cellulose, constitute a small number in range 1,02-1,60\% and 5,10-5,77\% for Tsarevych and 0,98$1,53 \%$ and $4,75-5,73 \%$ in Ulus variety, that's why there is no significant effect from technology growing methods on content of these matters. 


\section{Conclusion}

The maximum yield of pea grains 4,01 t/ha in the sort Tsarevych and 4,31 t/ha in the sort Ulus was formed by using Ryzohumin and Polimiksobakteryn inoculating of seeds and conducting foliar fertilizing by KODA Foul 7-21-7 in the phases of budding and beans formation and KODA complex in the phase of ripening seeds, which is bigger on 1,04 and $1,16 \mathrm{t} / \mathrm{ha}$ in comparison to the control. The biggest crude protein output in the sort Tsarevych - 1,02 t/ha and in the sort Ulus $1,07 \mathrm{t} / \mathrm{ha}$ is obtained on the same variant. The sufficient attention is given to increasing crop yields through the use of micronutrients in scientific workshops and conferences. Investigations of scientific institutions confirm the necessity of foliar fertilizing field crops by complex fertilizers, which containing stimulants, amino acids, micronutrients. However, these agricultural practices are causing a lot of questions, that's why we were conducted the research of optimization the mineral nutrition of pea, systematized the results of microbiological interaction and complex fertilizers on the yield and its quality with recommendations for agricultural producers.

\section{References}

Babich, A. (1994). Feed plants and fodder resources of the world. Feed and feed protein. P. 6-10.

Babich, A., Petrychenko, V., Adamets, F. (2008). Problems photosynthesis and biological nitrogen fixing legume crops. Bulletin of Agricultural Science. No 2, pp: 34-39.

Bandura, V., Mazur, V., Yaroshenko, L., Rubanenko, O. (2019). Research on sunflower seeds drying process in a monolayer tray vibration dryer based on infrared radiation. INMATEN - Agricultural Engineering, 57 (1) :233-242.

Ermakov, A., Arasymovych, V., Yarosh, N. et al. 1987. Methods Studies biochemically plants. L.: Agropromizdat, P. 430.

Ishchenko, V., Belyakov, A. (2009). Efficiency of micronutrients, growth regulator and ryzohuminu in increasing productivity varieties of peas without leaves type. Steppe Bulletin. 6:37-41.

Kolesnik, S. (2012). Bacterial fertilizer to optimize nitrogen and phosphorus nutrition soybeans, chickpeas, peas, lentils and commit. Feed and fodder. 73:145-151.

Mazur, V.A., Pantsyreva, H.V., Mazur, K.V., Didur, I.M. (2019). Influence of the assimilation apparatus and productivity of white lupine plants. Agronomy research. 17(1), 206-219.

Mazur, V.A., Didur, I.M., Pantsyreva, H.V., Telekalo, N.V. (2018). Energy-economic efficiency of grain-crop cultures in the conditions of the right-bank Forest-Steppe of Ukraine. Ukrainian J Ecol, 8(4), 26-33.

Mazur, V. A., Myalkovsky, R.O., Mazur, K. V., Pantsyreva, H. V., Alekseev, O.O. (2019). Influence of the Photosynthetic Productivity and Seed Productivity of White Lupine Plants. Ukrainian Journal of Ecology, 9(4), 665-670.

Malchevskaya, E., Mylenkaya, G. (1981). The comments and Animal Husbandry quality forage analysis. Minsk . Harvest, P. 143.

Melnychuk, T., Patyka, V. (2011). Microbial preparations bioorganic farming system. Collected articles "Third All-Ukrainian Congress of Ecologists with international participation." Vinnytsya. Tom.2: 423-426.

Telekalo N., Mordvaniuk M., Shafar H., Matsera O. (2019). Agroecological methods of improving the productivity of niche leguminous crops/ Ukrainian Journal of Ecology. №9(1). 169-175.

Ovcharuk, V.I., Mulyarchuk, O.I., Myalkovsky, R.O., Bezvikonnyi, P.V., et al. (2019). Parameters of beet plants. Bulletin of the Uman National University of Horticulture. № 1. P. 70-75.

Pantsyreva, H.V. (2019). Morphological and ecological-biological evaluation of the decorative species of the genus Lupinus L.. Ukrainian Journal of Ecology, 9(3), 74-77.

Pantsyreva, H.V. (2019). Morphological and ecological-biological evaluation of the decorative species of the genus Lupinus L.. Ukrainian Journal of Ecology, 9(3), 74-77.

Pantsyreva, H.V. (2019). Technological aspects of biogas production from organic raw materials. Bulletin of KhNTUSG them. P. Vasilenko. Kharkiv, 2019. P. 276-290.

Pantsyreva H.V. (2018). Research on varietal resources of herbaceous species of Paeonia L. in Ukraine. Scientific Bulletin of the NLTU of Ukraine, 28 (8), 74-78. https://doi.org/10.15421/40280815

Skoromna, O.I., Razanova, O.P., Tkachenko, T.Y. (2019). Effect of lysine feeding allowance on growth performance and carcass characteristics of growing pigs. Ukrainian Journal of Ecology, 9(4), 646-650.

Telekalo, N. (2014). Effect of inoculation and foliar fertilizings on yield varieties peas. Legumes and cereals cultures. (9): 16-22.

Vdovenko, S.A., Prokopchuk, V.M., Palamarchuk, I.I., Pantsyreva, H.V. (2018). Effectiveness of the application of soil milling in the growing of the squash (Cucurbita pepo var. giraumontia) in the right-benk forest stepp of Ukraine. Ukrainian J Ecol, 8(4), 1-5.

Vdovenko, S.A., Pantsyreva, G.V., Palamarchuk, I.I., Lytvyniuk, H.V. (2018). Symbiotic potential of snap beans (Phaseolus vulgaris L.) depending on biological products in agrocoenosis of the right-bank forest-steppe of Ukraine. Ukrainian J Ecol, 8(3), 270-274.

Vitalii, P., Inna, H., Tetiana, H., Natalia, T. (2018). Effect of the elements of corn cultivation technology on bioethanol production under conditions of the right- bank forest-steppe of Ukraine. Ukrainian Journal of Ecology. 2018. №8(3). 47-53.

\section{Citation:}

Mazur, V., Didur, I., Myalkovsky, R., Pantsyreva, H., Telekalo, N., Tkach, O. (2020). The Productivity of intensive pea varieties depending on the seeds treatment and foliar fertilizing under conditions of right-bank forest-steppe Ukraine. Ukrainian Journal of Ecology, 10(1), $101-105$. 